DOI: https://doi.org/10.5007/1980-3532.2016n16p15

\title{
Veja e CartaCapital: a polarização política das páginas às ruas
}

\author{
Veja and CartaCapital: the political polarization from the paper \\ to the streets
}

Otávio Vicente Hoffmann de Matos Faculdade Satc/Criciúma - SC Bacharel em Jornalismo otaviomatos03@hotmail.com

Claudia Nandi Formentin Faculdade Satc - Criciúma/SC

Doutora em Ciências da Linguagem (Unisul/SC) Professora no curso de Jornalismo da Satc/SC formentinnandi.claudia@gmail.com

Resumo: Este artigo é um estudo de caso que tem como objetivo analisar a abordagem das revistas Veja e CartaCapital nas edições posteriores às eleições de 2014. Por meio de pesquisa bibliográfica, têm-se o objetivo de responder à seguinte questão: na abordagem das matérias das revistas Veja (5 e 12 de novembro de 2014) e CartaCapital (29 de outubro de 2014 e 5 de novembro de 2014), nas edições que sucederam as eleições para a presidência naquele ano, é possível verificar a polarização política no discurso? Através da análise de trechos de matérias das duas revistas, buscou-se mostrar como a ideologia é colocada nos textos e como o discurso fala mais do que as palavras podem mostrar. Isso acontece, especialmente, observando os silêncios e os pressupostos do discurso. A partir disso, concluiu-se que as duas revistas buscam defender um lado, CartaCapital a candidata vencedora no pleito e Veja a oposição desta. Concluiu-se que as duas revistas agem de forma a acirrar a polarização política que é vista nas ruas.

Palavras-chave: Eleições 2014. Veja, CartaCapital. Discurso. Polarização política.

\begin{abstract}
This paper is a study case that aims to analyze the approach of the issues released by the magazines Veja and CartaCapital after the 2014 election in Brazil. Its goal is to answer through bibliographic research the following question: is it possible to ascertain any discursive polarization in the issues published by Veja (released on the 5th and 12th of November 2014) and CartaCapital (released on the 29th of October 2014 and 5th of November 2014) after the presidential election in that year in Brazil? It has sought to show how their ideology is placed in their articles and how their speech has more meaning than words can express. This happens, especially, by observing the silences and presuppositions of the discourse. It has been concluded that both magazines have chosen a specific party to support, CartaCapital has chosen the winner party while Veja has chosen the opposition. It is concluded that the two magazines act in a way to intensify the political polarization that is seen in the streets pointing to a bright and a dark side.
\end{abstract}

Keywords: 2014 election. Veja. CartaCapital. Speech. Political polarization.

Originais recebidos em: 23/02/2017

Aceito para publicação em: 10/08/2017

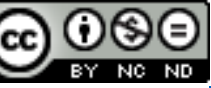

Este trabalho está licenciado sob uma Licença Creative Commons Atribuição-Uso Não-Comercial-Vedada a criação de obras derivadas 3.0 Unported License.

Revista Em Debate (UFSC), Florianópolis, volume 16, p. 15-40, 2016. ISSNe 1980-3532 


\section{Introdução}

Durante o período eleitoral de 2014, ficou evidente a divisão do país em dois polos políticos, principalmente nas eleições para o segundo turno, quando Dilma Rousseff (PT) - 51,64\%, venceu Aécio Neves (PSDB) - 48,36\%. No jornalismo, as revistas Veja e CartaCapital acirraram a disputa pela presidência através de matérias que demonstravam mais atacar o opositor do que apoiar seu candidato. Isso, de certa forma, acabou criando um clima de disputa entre as duas publicações de linhas editoriais totalmente divergentes. Além disso, demonstrou o que nas ruas já se via: a polarização da sociedade brasileira no que tange o aspecto político.

No entanto, da mesma forma como a polarização é demonstrada pelas revistas, as publicações também acabam por acirrar os ânimos dos eleitores, sejam militantes ou tão-somente interessadas pelos assuntos que cerceiam a política nacional.

A CartaCapital, durante a campanha de Dilma, anunciou em editorial que apoiaria a candidata petista, mostrando a seus leitores o que, provavelmente, encontrariam nas páginas da revista - um posicionamento pró-PT. Já a Veja há muito ataca, através de editoriais e matérias, o Partido dos Trabalhadores, mesmo sem declarar seu voto para o candidato da oposição.

A revista Veja foi fundada por Mino Carta, junto com Roberto Civita, diretor da Abril até seu falecimento, em maio de 2013. Veja nasceu no ano em que foi instituído o Ato Institucional número 5 - AI-5 -, que tolheu os direitos da imprensa, censurando jornais e revistas, entre elas, a própria Veja. Logo de início, a revista tinha uma tiragem de 650 mil exemplares. Este número caiu para meros 16 mil no fim de 1968, mesmo ano da inauguração. $\mathrm{O}$ aumento nas vendas só veio após algumas alterações feitas por Mino Carta, em 1969, como, por exemplo, as Páginas Amarelas, uma seção de entrevistas, que se mantém até os dias atuais.

Segundo Scalzo (2006), as vendas começaram a subir após o lançamento de um modelo de assinatura, em 1971. Hoje, é a revista "mais vendida do Brasil, a única semanal de informação no mundo a desfrutar de tal situação. Em outros países, revistas semanais de informação vendem bem, mas nenhuma é a mais vendida" (SCALZO, 2006. p. 31).

Já CartaCapital, publicada pela editora Confiança, outro foco de análise deste artigo, foi fundada em 1994, com periodicidade mensal. O fundador da publicação foi Revista Em Debate (UFSC), Florianópolis, volume 16, p. 15-40, 2016. ISSNe 1980-3532 
Mino Carta, que ao ser demitido de Veja em 1975 ainda lançou a semanal IstoÉ, onde ficou até 1993. A revista se mantém até hoje. Em CartaCapital, Mino decidiu abrir mão das vendas e focar em conteúdo diferenciado.

Segundo Mino Carta, no primeiro editorial da revista - divulgado pelo Mídia $\mathrm{Kit}^{1}$, disponível na internet -, ela surgiu com o objetivo de ser fiel à verdade dos fatos, com análises críticas e fiscalização do poder, dando aí a tônica de como seriam as abordagens dali em diante. Carta (1994) ainda enfatiza que "nada disso resulta na intenção de impor ideias, e sim estimular o espírito crítico dos próprios leitores na elaboração de opiniões independentes, do pensamento nosso ou de quem quer que seja" (CARTACAPITAL, 1994).

A forma como lidam com assuntos referentes à política é a grande semelhança entre as revistas. Ambas dão destaque a esta editoria e também acabam se posicionando ideologicamente. Uma se posicionando mais à direita outra mais à esquerda. CartaCapital já se posicionou politicamente de modo claro por meio de editoriais. Como em 2014, quando Mino Carta esclareceu em editorial "Por que escolhemos Dilma Rousseff" (CARTACAPITAL, 2014).

Veja nunca declarou seu posicionamento ideológico, tornando obscuro e ainda mais interpretativo o material publicado em suas páginas. Por serem antagônicas e por darem tanta atenção à editoria de política é que elas merecem atenção especial nesta pesquisa. Por exercerem grande influência na sociedade é que elas são importantes para evidenciar a polarização política no país.

Além da presença no impresso, semanalmente, Veja e CartaCapital também potencializam seu alcance nas redes sociais, em seus sites, enfim. Seabra (2006) cita os meios eletrônicos de comunicação como um dos marcos das mudanças que ocorrem com o jornalismo político atual, citando blogs e sites que alimentam a discussão política da população.

Para tanto, foi elencado como objetivo deste trabalho analisar os discursos das matérias das revistas Veja e CartaCapital nas edições posteriores à votação do $2^{\circ}$ turno de 2014. Este objetivo vai servir para responder ao problema central do trabalho, que é: na abordagem das matérias das revistas Veja e CartaCapital, nas edições que sucederam

\footnotetext{
1 Disponível em https://www.editoraconfianca.com.br/formatos_html/assets/editoraconfianca_20 07.pdf (Acesso em 23 de fev. de 2017)

Revista Em Debate (UFSC), Florianópolis, volume 16, p. 15-40, 2016. ISSNe 1980-3532
} 
as eleições para a presidência em 2014, é possível verificar a polarização política no discurso dos veículos mencionados?

Para a análise de dados subsequente, foram utilizadas duas edições de cada revista, nas duas semanas após a reeleição de Dilma Rousseff à presidência do país. Sendo elas as edições 823, de 29 de outubro, e 824, de 5 de novembro, da CartaCapital. Em suas manchetes, ela traz na primeira edição um caderno especial das eleições e, na segunda, os desafios que Dilma enfrentaria no segundo mandato, com análises de políticos e economistas, dando enfoque no Ministério da Fazenda, que à época não tinha ministro para ocupar o cargo, causando certo suspense sobre quem seria o responsável pelas finanças do país.

Na revista Veja, a edição 2398, de 5 de novembro, traz na capa, como manchete, a Operação Lava-Jato, da Polícia Federal, dando um enfoque menor na vitória do PT. Na edição seguinte, a 2399, de 12 de novembro, a revista foca em Dilma, com a manchete "A Solidão da Vitória", que fala sobre a crise econômica do país, a pressão do próprio partido e seu isolamento no Palácio do Planalto, em Brasília.

Para que se exponha a abordagem das revistas, o tratamento dado ao problema será qualitativo. Segundo Gil (2002), o analista deve "associar os dados recolhidos a um modelo teórico com a finalidade de compará-los” (2002, p. 90). Com isso, é possível "verificar se há verdadeiramente correspondência entre a construção teórica e os dados observados" (2002, p. 90). A Análise do Discurso, então, serviu como base para o desenvolvimento da análise dos dados coletados nas revistas aqui estudadas. Dois critérios que nortearam esta análise constituem-se nos silêncios e nos pressupostos do discurso. Os procedimentos técnicos: bibliográfico e estudo de caso.

\section{Análise do discurso}

Como descrito anteriormente, Veja e CartaCapital são das revistas mais importantes do país, principalmente no que diz respeito à editoria de política. Compreender o que os enunciados em si significam é muito importante para compreende a mensagem real que as matérias das revistas querem dizer, além das capas que foram analisadas. Por isso o assunto tratado aqui será a Análise do Discurso.

A mídia é um meio importante e influente na sociedade como um todo, moldando a maneira com que as pessoas pensam, agem e podendo até tornar o Revista Em Debate (UFSC), Florianópolis, volume 16, p. 15-40, 2016. ISSNe 1980-3532 
consumidor, o leitor, um condutor do fio ideológico da publicação. Liedtke (2002) coloca a mídia como principal agente discursivo da sociedade, com o poder de formar e manter o discurso hegemônico de um partido, ou de sua oposição, se for o caso (LIEDTKE, 2002). Esta não é uma percepção feita no século XX. Velloso (2006, p. 314) ao tratar das revistas publicadas entre o final do século XIX e a primeira metade do século XX destaca este veículo "como lugar de estruturação das redes de sociabilidade, conformando um microcosmos - em relação ao livro - de organização e de atuação dos intelectuais".

A mídia sofre influência da política, mas o efeito inverso também é notado. Ou seja, a política também sofre influência da mídia. Sobre o primeiro poder, da mídia sobre a política, Mariani destaca a afirmação da hegemonia do discurso político, mas também de sua contrariedade. "A mídia funciona, neste sistema, como um elemento fundamental na representação e re-produção dos 'consensos de significação' resultantes das hegemonias políticas ou, ao contrário, participa da sua dissolução" (MARIANI, 1996, p. 46).

Pode-se afirmar, com isso, que a mídia é uma mantenedora do discurso hegemônico, mas que também pode trabalhar na desconstrução dessa hegemonia. Usando como exemplo as duas publicações estudadas neste trabalho, é possível apontar CartaCapital como apoiadora da candidata da esquerda, como uma publicação que busca manter a hegemonia do partido que estava no poder - e que ganhou, nas urnas, o direito de permanecer no posto por mais quatro anos. Isso, claro, se não houvesse havido o impeachmet, quando Michel Temer (PMDB), então vice-presidente, assumiu o posto mais alto do Poder Executivo no país, onde está até hoje. Do outro lado, tem-se a Veja, que busca diluir esta hegemonia, com o viés da oposição. No entanto, neste trabalho de retirada da hegemonia de quem se inscreve no poder, a Veja acaba se inserindo no discurso hegemônico da oposição, buscando mantê-lo também.

Liedtke (2002) coloca, então, que "grande parte das significações que alimentam a memória discursiva do cenário político encontram nos meios de comunicação sua materialização" (LIEDTKE, 2002, p. 77). Isso quer dizer que tudo o que está inserido nas revistas, em forma de texto, e que será analisado mais adiante neste trabalho é uma construção, uma afirmação de algo ocorrido, resgatado através da memória do discurso de outrem, e que causará outras interpretações e, por consequência, outras memórias. 
Análise do Discurso e ideologia se juntam em diversos momentos. Para descrever uma ou outra, geralmente é necessário citar as duas coisas. Quando um discurso é analisado, não é o sentido explícito, superficial que é procurado, mas o sentido real, mais profundo, que está ligado à ideologia. É preciso levar em conta o passado do emissor, a história que liga ele ao enunciado. "Uma mesma palavra, na mesma língua, significa diferentemente, dependendo da posição do sujeito e da inscrição do que diz em uma ou outra formação discursiva" (ORLANDI, 2007, p. 60). A análise também se dá através da interpretação, para que se possa descrever o que realmente está dito.

Em se tratando de discurso, existe também o já-dito, o dito e o não-dito. $O$ primeiro trata do que há por trás do discurso, algo anterior à fala. $\mathrm{Na}$ análise é preciso trabalhar com o dito e o não-dito. O não-dito é o implícito, ele trata daquilo que fica ou pressuposto, do ponto de vista da linguagem, ou subentendido, quando visto pelo contexto. Orlandi (2007) traz exemplos que clareiam estes dois termos: "Se digo 'Deixei de fumar' o pressuposto é que eu fumava antes (...) mas o motivo, por exemplo, fica como subentendido" (ORLANDI, 2007, p. 82). Dessa forma, pode-se concluir que o pressuposto é o que está por trás do dito. Quanto ao subentendido, é preciso levar em consideração o contexto. Neste caso, é o que levou a pessoa a parar de fumar.

Maingueneau (2002) segue o mesmo caminho de Orlandi neste assunto. Considerando o contexto da placa "não fumar" em uma sala de espera, ele insere a seguinte frase: Paul deixou de fumar na sala de espera. E explica:

Pode-se tirar o pressuposto de que antes ele fumava. Esse conteúdo implícito está no enunciado, mas subtraindo-se a qualquer contestação, como se se tratasse de uma evidência. (MAINGUENEAU, 2002, p. 33)

Com isso, é possível tirar a conclusão de que se algo fica pressuposto em um texto é porque não precisa estar ali para ter esta interpretação. Já o subentendido vem de uma interpretação que o receptor precisa fazer, considerando o contexto do enunciado.

Vale apresentar também outra forma de não-dito na análise de discurso: o silêncio. Existe o silêncio fundador, que indica um outro sentido ao discurso; o silêncio constitutivo, que diz respeito a uma palavra que apaga outras palavras; o silêncio local é a censura, o que não é permitido ser dito, como uma ditadura, por exemplo.

Neste artigo, o termo "discurso" será tratado dentro das ciências da linguagem. Para isso, têm-se algumas características, citadas por Maingueneau (2002). Uma delas é 
de que "o discurso é uma organização situada para além da frase" (MAINGUENEAU, 2002, p. 52). Isso quer dizer que ele traz junto de si estruturas de outra ordem, ou seja, pelo que vem antes da palavra também.

Em um sentido linguístico, o enunciado é considerado simétrico. O receptor se vale da gramática da língua para compreender o sentido do texto. Já na linguagem, o sentido é considerado assimétrico. Maingueneau (2002) chama atenção para este fato, alertando para o risco que isso impõe. "A pessoa que interpreta o enunciado reconstrói seu sentido a partir de indicações presentes no enunciado produzido, mas nada garante que o que ela reconstrói coincida com as representações do enunciador" (MAINGUENEAU, 2002, p. 20). Com isso, o autor diz que um enunciado permite ao interpretante criar hipóteses, construir um contexto que não está visível. E é isso que será feito no capítulo dedicado à análise dos dados coletados das revistas Veja e CartaCapital.

Em relação ao contexto, Maingueneau (2002) explica três fontes de informações para eles: o ambiente físico da enunciação, ou contexto situacional; o cotexto; e os saberes anteriores à enunciação. No primeiro, vale o contexto que diz respeito à situação do sujeito, o presente do verbo, o lugar onde ele está.

O segundo contexto "são as sequências verbais encontradas antes ou depois da unidade de interpretar. [...] Os enunciados geralmente são fragmentos de uma totalidade mais ampla" (MAINGUENEAU, 2002, p. 27). Neste caso, o enunciado está ligado à memória, a um contexto mais amplo. Por exemplo, a palavra "família" que, em uma frase, significará uma família específica, mas também o conceito de família, em um sentido mais amplo.

Em último, vêm os saberes anteriores à enunciação, que têm como exemplos, citados por Maingueneau (2002) "a referência dos nomes próprios ou os conhecimentos a respeito das consequências prejudiciais do tabaco, o formador oficial dos avisos de interdições etc" (MAINGUENEAU, 2002, p. 27). Em um exemplo de seu livro, o autor (2002) traz uma placa com a escrita "Não fumar". Nesta última fonte de informação citada, esta frase carrega em seu contexto o local onde está exposta, a forma como está inserida neste local. Daí, os saberes anteriores à enunciação.

O discurso possui algumas leis, que garantem melhor interpretação dos enunciados e suas relações. Maingueneau elenca cinco: a da pertinência, a da sinceridade, a da informatividade, da exaustividade e, por fim, a da modalidade. Vamos Revista Em Debate (UFSC), Florianópolis, volume 16, p. 15-40, 2016. ISSNe 1980-3532 
a elas: a lei da pertinência fala que uma enunciação deve interessar ao destinatário, mantendo-se fielmente adequada ao contexto. (MAINGUENEAU, 2002). Se a revista Veja, por exemplo, diz na manchete que há esquema de corrupção na política brasileira, em seu conteúdo ela precisa falar disso, mostrar isso. A lei da sinceridade interessa menos para os propósitos deste trabalho, por situar mais o engajamento da fala do enunciador.

A lei da informatividade "incide sobre o conteúdo dos enunciados e estipula que não se deve falar para não dizer nada, que os enunciados devem fornecer informações novas ao destinatário" (MAINGUENEAU, 2002, p. 36).

Já a exaustividade exige que o enunciado conceda a informação máxima. Se a revista CartaCapital divulga a informação de que R 100 milhões foram desviados dos cofres públicos, estima-se que este seja o teto do desvio e não a metade do dinheiro. Caso a revista dissesse que $\mathrm{R} \$ 50$ milhões foram desviados, ela não estaria errada, desde que não colocasse este valor como o máximo.

Mas, para evitar equívocos, a lei exige que a informação máxima seja repassada. "A lei da exaustividade exige também que não se esconda uma informação importante" (MAINGUENEAU, 2002, p. 36). Poderia ser considerado, a título de exemplificação, que o partido político de um deputado envolvido em corrupção tenha que ser divulgado, pois é uma informação pertinente ao eleitor.

Uma última lei ainda é explicitada por Maingueneau (2002). A lei da modalidade "prescreve clareza (na pronúncia, na escolha das palavras, na complexidade das frases, etc.) e, principalmente economia (procurar a formulação mais direta)" (MAINGUENEAU, 2002, p. 37). Isso quer dizer que usar palavras confusas ou ambíguas, por exemplo, é considerado quebra desta norma que, para a comunicação, é de suma importância para uma compreensão clara do enunciado.

Outra parte importante no presente estudo, e como complemento desta base sobre Análise do Discurso, são as formações ideológicas, formações discursivas e condições de produção. Estes itens serão explicados a seguir.

\section{Formação ideológica, formação discursiva e condições de produção}

O discurso coloca à mesa a materialidade da ideologia. Para analisar a articulação da ideologia, é preciso explanar sobre alguns conceitos da Análise do Revista Em Debate (UFSC), Florianópolis, volume 16, p. 15-40, 2016. ISSNe 1980-3532 
Discurso: formação ideológica, formação discursiva e as condições de produção. Orlandi (2007) aponta as condições de produção do discurso como um fator importante na percepção deste. Nestas condições, faz-se valer a memória do indivíduo, onde se esconde o contexto ideológico do sujeito. O contexto imediato do discurso é percebido quando as condições de produção são levadas em conta em um sentido estrito. "E se as consideramos em sentido amplo, as condições de produção incluem o contexto sóciohistórico, ideológico" (ORLANDI, 2007, p. 30).

As formações ideológicas se constituem no embate entre as posições políticas e ideológicas, que servem como forma de reafirmação da classe dominante a que o sujeito pertence. A partir deste momento, surgem então as formações discursivas, como componentes das formações ideológicas. "Isso significa que os discursos são governados por formações ideológicas" (BRANDÃO, 2004, p. 47). As formações discursivas são constituídas por dois tipos de funcionamento:

O primeiro é pela paráfrase e pela polissemia. Neste primeiro conceito, os enunciados são feitos e refeitos a cada momento. A polissemia irrompe as barreiras criadas pela paráfrase, embaralhando os limites de começo e fim de um discurso, tornando-o mais plural. O segundo conceito é o pré-construído, constituído pela construção anterior e exterior do discurso, se opondo ao que foi dito pelo enunciado (BRANDÃO, 2004).

Por se aprofundar mais no que é dito pelo enunciado, o funcionamento préconstruído é mais pertinente para ser usado neste trabalho, em que enunciados serão analisados, no próximo capítulo. O pré-construído impõe uma realidade, pela interpelação do sujeito pela ideologia.

Assim, o pré-construído, entendido como "objeto ideológico, representação, realidade" é assimilado pelo enunciador no processo do seu assujeitamento ideológico quando se realiza sua identificação, enquanto sujeito enunciador, com o Sujeito Universal da FD. (BRANDÃO, 2004, p. 49)

O pré-construído, pode-se concluir, ocorre pelo assujeitamento, ou seja, pela apropriação de um discurso através da ideologia. O sujeito universal, citado por brandão, é formado pela sensação de que o sujeito é integralmente responsável por seu discurso, como se definisse o que pode e deve ser dito e, mais ainda, enfatiza brandão (2004, p. 49) que "garante o que cada um conhece, pode ver ou compreender".

É como o discurso de uma revista, se ela seguir a mesma linha de conteúdo editorial em muitas matérias, em muitas edições, dará a impressão de que aquilo que foi Revista Em Debate (UFSC), Florianópolis, volume 16, p. 15-40, 2016. ISSNe 1980-3532 
publicado é verdade absoluta quando, na verdade, está sendo carregado pelo processo ideológico do discurso, influenciado pelas condições de produção, pelas formações discursivas e ideológicas.

Orlandi (2007) traz uma reflexão importante sobre estes processos, principalmente por, de forma indireta, usar como exemplo a questão política, dita "direita" e "esquerda", como é o caso das duas revistas que serão analisadas neste trabalho. Para dizer que um discurso é de direita ou de esquerda, é preciso ver além.

É preciso referi-lo às suas condições de produção, estabelecer as relações que ele mantém com sua memória e também remetê-lo a uma formação discursiva - e não outra - para compreendermos o processo discursivo que indica se ele é de esquerda ou de direita. Os sentidos não estão nas palavras elas mesmas. Estão aquém e além delas. (ORLANDI, 2007, p. 42)

Com isso, pode-se perceber a complexidade de cada discurso, em cada conjunto de palavras. Também é possível notar a concordância no que dizem as duas autoras, em se tratando das formações do discurso. Orlandi (2007) fala da parte prática da análise de discurso, na qual o analista emprega seu trabalho. Ela coloca as formações discursivas como essenciais neste trabalho, pois só assim torna-se possível compreender as condições de produção e as formações ideológicas, bem como as regularidades do discurso, ou seja, se ele se repete e com qual frequência. "A formação discursiva se define como aquilo que numa formação ideológica dada [...] determina o que pode e deve ser dito" (ORLANDI, 2007, p. 43). Ainda por isso, ela coloca o entendimento da formação discursiva sob dois aspectos.

No primeiro, coloca a discursividade no centro das atenções, onde se manifestam as intenções do discurso, inscritas em uma formação e não em outra, representadas por suas formações ideológicas, através de traços ideológicos. Ela destaca a heterogeneidade das formações discursivas, que nunca se acabam em seu fim, dando início a outra, constituídas pela contradição. Nesta contradição, então, vale a metáfora da análise de discurso, pois aqui ela não é tratada como figura de linguagem. A metáfora, na análise de discurso é nada além do que a troca de uma palavra por outra, a transferência que estabelece a forma como as palavras significam (ORLANDI, 2007, p. 44).

No segundo aspecto da formação discursiva, Orlandi (2007) foca nos sentidos provocados pelo discurso, citando como exemplo a palavra "terra" que, dependendo do lugar do receptor, tem significado diferente, e cada interpretação diferente seria inserida em uma formação discursiva diferente. 
Orlandi (2007) explica, em um esquema, como funcionam as etapas de uma análise. Na primeira fase, o analista busca ver no texto a discursividade, construindo um objeto discursivo, considerando o primeiro esquecimento apresentado neste capítulo, que diz respeito ao enunciado. Na segunda etapa, o analista deve buscar relacionar as distintas formações discursivas presentes no texto, a fim de relacioná-las com as formações ideológicas, que regem essas relações. "Aí é que ele atinge a constituição dos processos discursivos responsáveis pelos efeitos de sentidos produzidos naquele material simbólico, cuja formulação o analista partiu" (ORLANDI, 2007, p. 77-78).

Após esta explanação acerca da Análise do Discurso e suas minúcias, é chegada a hora de analisar, de fato as revistas-alvo deste estudo.

\section{Apresentação e análise dos dados}

Para atingir o objetivo deste trabalho, de analisar os discursos das matérias das revistas Veja e CartaCapital nas edições posteriores à votação do $2^{\circ}$ turno de 2014, foram analisadas as edições 823 e 824 de CartaCapital, datadas de 29 de outubro e 5 de novembro, respectivamente. Em Veja, as edições 2398 e 2399, de 5 e 12 de novembro foram as escolhidas para análise. Vale relembrar que a problemática do trabalho visa responder se, com os dados coletados e analisados, é possível verificar a polarização discursiva no país.

A primeira capa (Figura 1) analisada é a da revista Veja, de 5 de novembro, logo após o segundo turno da eleição presidencial de 2014 que deu a vitória à Dilma Rousseff. Ao contrário do que se possa imaginar, o espaço central da capa silencia quanto as eleições tanto na manchete quanto na imagem. Nestes espaços o destaque é a Operação Lava-jato, da Polícia Federal, que investiga casos de corrupção na Petrobrás. Dilma se encontra lado a lado com seu concorrente no segundo turno das eleições, Aécio Neves, na parte superior da capa. Depois do título Mais quatro anos, a revista propõe um Manual de Sobrevivência para o segundo mandato de Dilma, enquanto com Aécio traz uma entrevista e destaca a seguinte frase: o Brasil perdeu o medo do PT. Aqui cabe avaliar que, apesar de a maioria da população ter votado na candidata do PT (51,64\%), a revista aponta para a exaustão. Há uma indicação de cansaço nas frases apresentadas pela publicação em expressões como 'mais' e 'manual de sobrevivência' 
(VEJA, 2014). Esta última indica a dificuldade que serão vividos nos anos posteriores à eleição sendo para isso necessário um manual, um guia.

Figura 1 - Capa de Veja em 5 de novembro de 2014

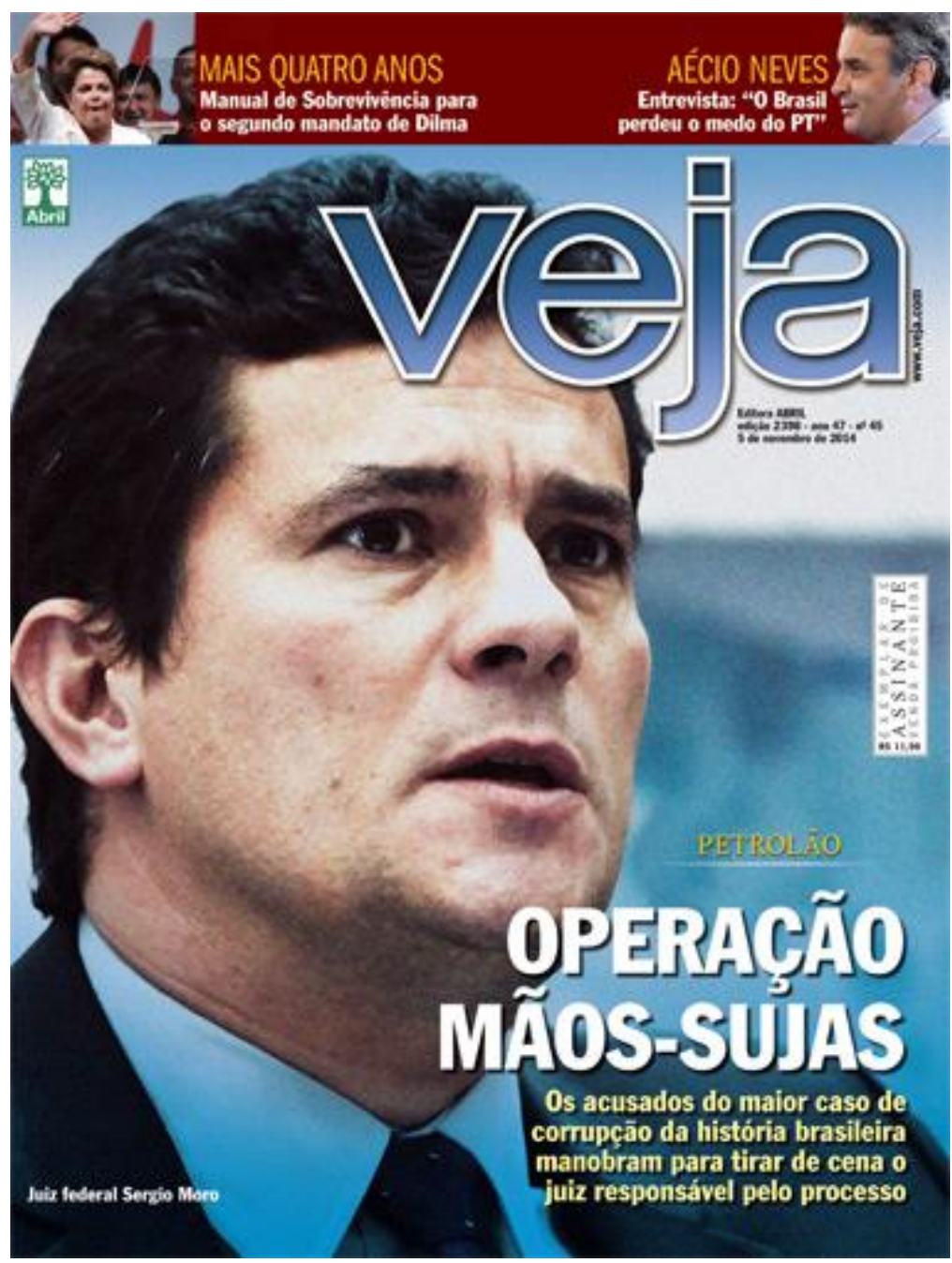

Fonte: Revista Veja (2014)

Ao destacar o juiz federal Sergio Moro e a Operação Lava-jato, chamada na manchete de Operação Mãos-sujas, sob a cartola de Petrolão, a revista mostra que seu foco é outro, não as eleições. Cabe aqui lembrar que antes da votação para o segundo turno Veja antecipou sua edição e colocou na capa Dilma e Lula, afirmando Eles sabiam de tudo!, ao referir-se à Lava-jato. Nesse sentido, ao destacar novamente o juiz federal a revista mantém uma linha e, mesmo não tratando diretamente da eleição, acaba por apontar para a relação entre Dilma e a operação da polícia Federal, ou seja é ela que está com as mãos sujas. Tal relação não aparece de maneira direta mas a associação dos diferentes enunciados levam o leitor a fazer esta relação. 
O termo Mãos-sujas aparece como um juízo de valor, de forma negativa, e pressupõe que algo de ruim pode acontecer, que alguém colocará as mãos na Lava-jato. Mãos essas que estão sujas de dinheiro de corrupção. Mãos-sujas, neste caso, é uma metáfora, uma troca de palavras, tal qual aponta Orlandi.

Ela não é considerada, como na retórica, como figura de linguagem. A metáfora é aquilo definida como tomada de uma palavra por outra. Na análise de discurso, ela significa basicamente "transferência", estabelecendo o modo como as palavras significam. (ORLANDI, 2007, p. 44)

Dessa forma, mãos-sujas é a substituição de lava-jato e, além da mudança da palavra, altera seu sentido e significado. Embora nesta edição de Veja não haja menção, o nome Mãos-sujas pode ser interpretado como uma conotação à Operação Mãoslimpas $^{2}$, deflagrada na Itália, na década de 1990. Esta operação desvendou um esquema de corrupção parecido com o da Lava-jato, em que empresas privadas pagavam propinas para garantir contratos com estatais, dentre outros atos ilícitos. Os culpados também foram descobertos através de delação premiada, como é feita na Lava-jato. Portanto Veja, mais uma vez, usa da distorção para ativar a memória do leitor.

Embaixo do título, em uma linha de apoio, a revista diz: os acusados do maior caso de corrupção da história brasileira manobram para tirar de cena o juiz responsável pelo processo (VEJA, 2014). É uma acusação o que eles fazem. O leitor dessa edição pode se perguntar: quem são os acusados a que a revista se refere e que manobras são essas, elas aconteceram quando? Não existem nomes citados, mas há o implícito aqui, o silêncio que pode levar a tais questionamentos e a suas respostas. O silêncio é uma forma de o não-dito se manifestar. Dentre os tipos de silêncio elencados por Orlandi, neste caso se apresenta o silêncio fundador. "Este pode ser pensado como a respiração da significação, lugar de recuo necessário para que se possa significar, para que o sentido faça sentido [...] indica que o sentido pode sempre ser outro" (ORLANDI, 2007, p. 83).

Fica subentendido que o PT tentará a manobra de tirar Moro do processo. O subentendido é, segundo Orlandi (2007), o resultado da contextualização da mensagem. “Tirar de cena" indica que não é algo feito por vontade própria, mas o contrário, ou seja,

$2 \quad$ Disponível
http://www.bbc.com/portuguese/noticias/2014/11/141115 maos_limpas_italia_ru (Acesso em 6 de jan.
de 2017)

Revista Em Debate (UFSC), Florianópolis, volume 16, p. 15-40, 2016. ISSNe 1980-3532 
Sergio Moro, aponta Veja, será obrigado a sair da cena da Lava-jato. Nesse sentido a revista parece indicar certo diálogo entre as duas edições.

O Manual de Sobrevivência, da edição de 5 de novembro, demonstra que a presidente reeleita encontrará dificuldades no novo mandato, sobretudo com a oposição. Ao mesmo tempo indica que a população também precisará de um manual para sobreviver aos próximos quatro anos. Isso é confirmado com a afirmação de Aécio Neves, logo ao lado, dizendo que o Brasil perdeu o medo do PT. Os termos "medo" e "sobrevivência" aparecem também como juízo de valor. Atrás dessa afirmativa pode estar uma interrogação, levantada aqui: o Brasil tinha medo do PT? Este jogo de sentidos, lado a lado, mostra um padrão, uma regularidade no discurso da revista. Eles vão seguir sendo oposição ao governo do PT durante este segundo mandato. Isso aparece através do não-dito (ORLANDI, 2007), que é o que está por trás do enunciado.

A segunda capa (Figura 2), também da Veja, é do dia 12 de novembro. Nela, a manchete é de Dilma Rousseff, e chama atenção para a solidão dela após a vitória. As demais matérias que aparecem na capa não falam de política, por isso não foram analisadas.

"A solidão da vitória" é o que diz a revista, com uma foto de Dilma em uma expressão de decepção, tristeza, abandono. A linha de apoio diz que ela não sabe o que fazer na economia, está pressionada pelo PT e esnobada pelos aliados. Por isso, isolouse no Palácio do Planalto. "Esnobada" é um juízo de valor que leva a entender que ninguém está se importando com ela. Logo após a eleição, a Veja não destacou a vitória petista. Só fez isso depois de uma semana. O não-dito aqui se destaca mais uma vez, pois os motivos aos quais levaram ela a estar solitária podem ser os mais variados, já que o país vivia uma crise econômica e política, com a oposição, mesmo derrotada na eleição presidencial, crescendo em todo o Brasil. Fica subentendido, então, que a oposição será mais importante para a revista. Orlandi esclarece que "o subentendido depende do contexto. Não pode ser asseverado como necessariamente ligado ao dito" (2007, p. 82). Aqui, cabe destacar, há uma indicação de contexto na segunda edição para as questões apontadas na primeira, com seu manual de sobrevivência. Ora, se a presidente não sabe o que fazer com a economia, o que será da população? Precisará de um manual de sobrevivência. Há um algo que foi dito, que contextualiza o subentendido. 
Figura 2 - Capa de Veja em 12 de novembro de 2014

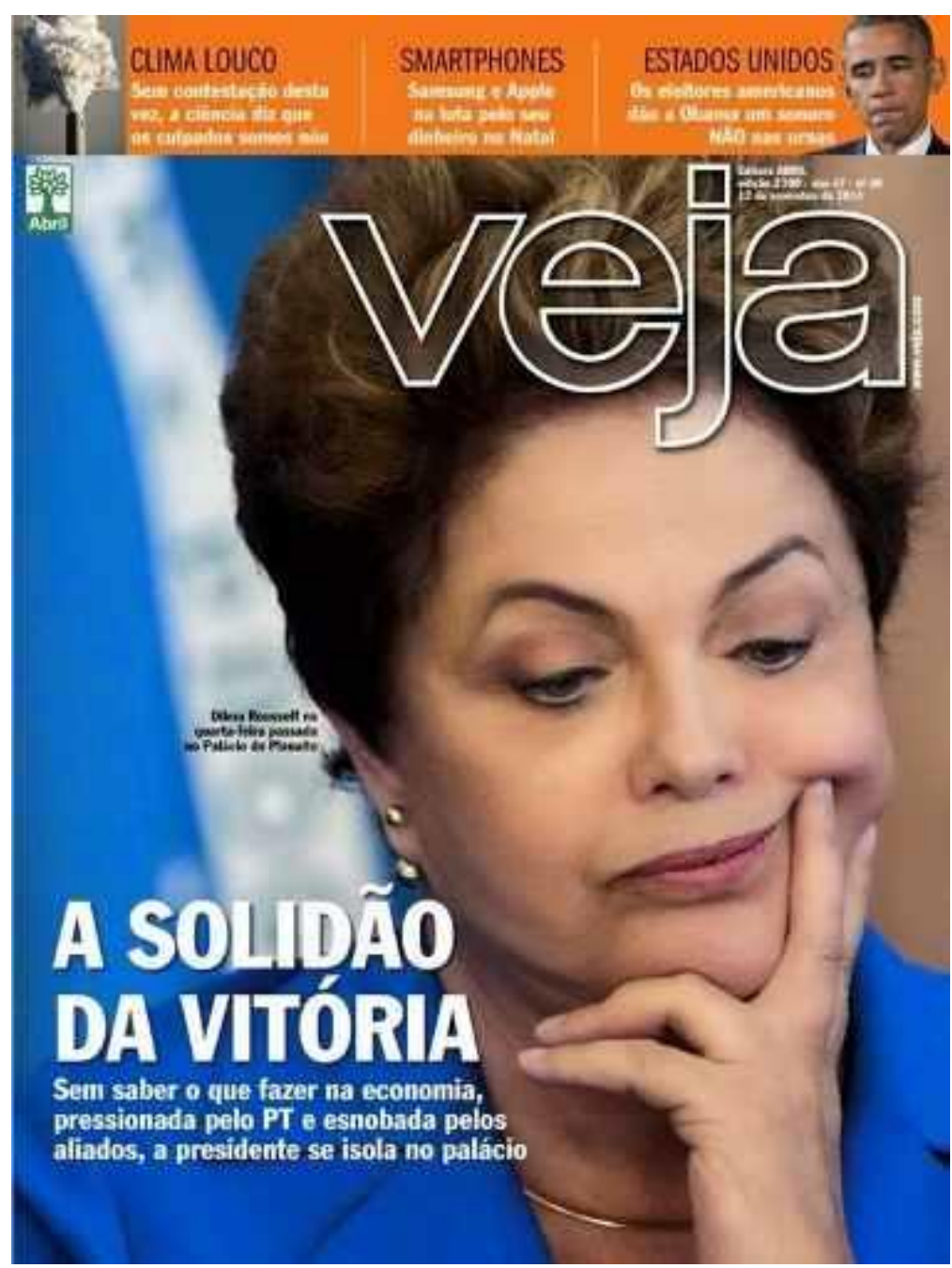

Fonte: Revista Veja (2014)

Por sua vez, a revista CartaCapital, na edição 823, de 29 de outubro (figura 3), primeira edição pós-vitória do PT, traz na capa Dilma Rousseff comemorando junto ao povo, sem manchete alguma, em um Especial Eleições.

Acima da marca da revista aparece "especial eleições" em caixa alta, pouco menor que o próprio nome da revista. O que pode ser analisado, neste caso, é que provavelmente CartaCapital já havia preparado uma edição especial em caso de vitória petista. Sem manchetes, somente com Dilma em uma expressão de alívio, felicidade e com uma multidão desfocada ao fundo, em volta dela. Isso dá a entender, também, que a edição trará em seu especial das eleições um destaque muito maior à vitória de Dilma e menos ao contexto das eleições como, por exemplo, a vitória por poucos pontos percentuais, reação do oponente ou mesmo de questões relacionadas as investigações da Revista Em Debate (UFSC), Florianópolis, volume 16, p. 15-40, 2016. ISSNe 1980-3532 
operação Lava-jato. Ou seja, percebe-se que há, também por parte de Carta Capital, silenciamento no que tange temas que, de alguma forma, se relacionam com a candidata eleita.

Figura 3 - Capa de CartaCapital em 29 de outubro de 2014

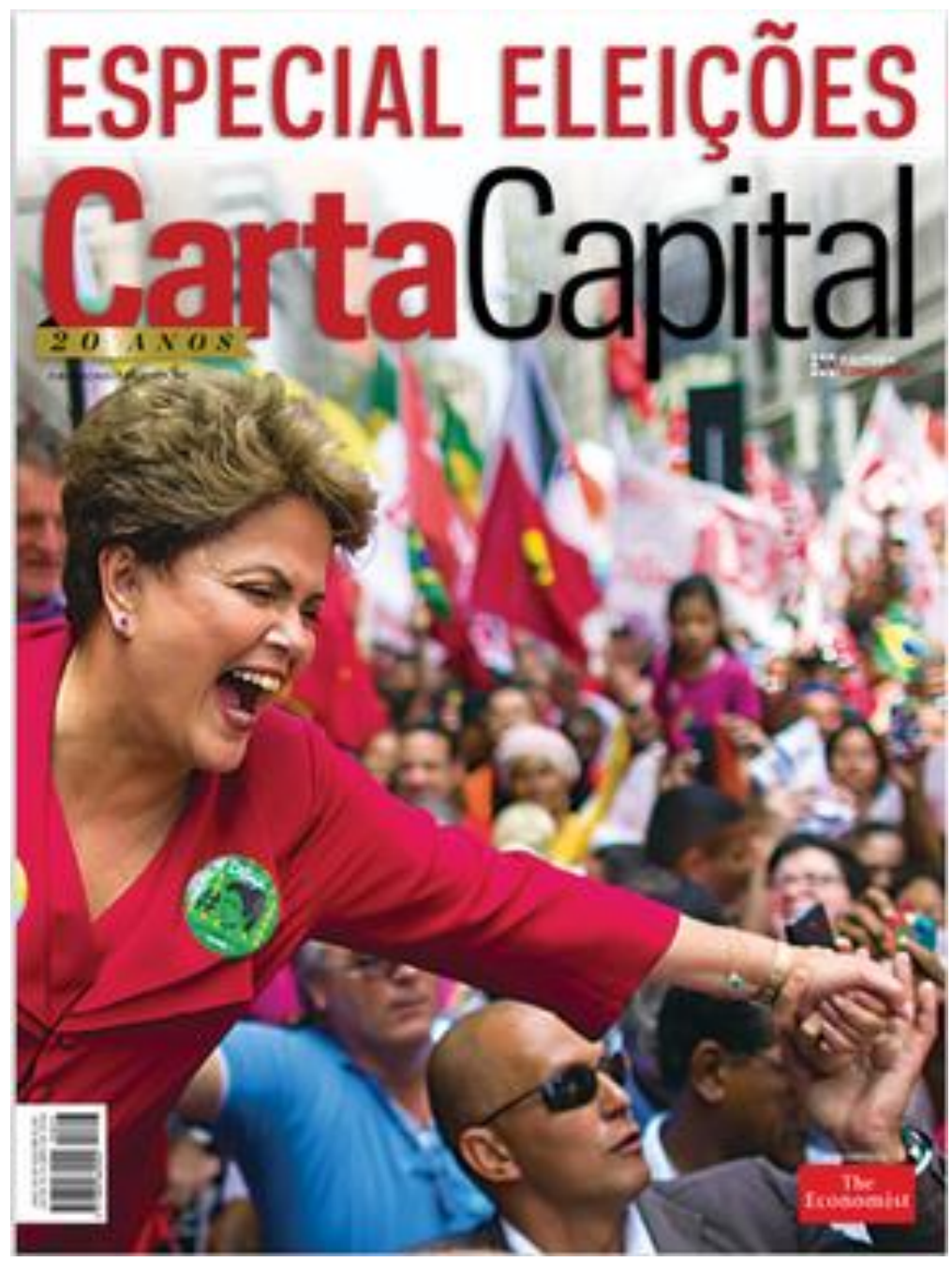

Fonte - Revista CartaCapital (2014)

As condições de produção, trazidas por Orlandi (2007), nesse caso, precisam ser analisadas. CartaCapital assumiu, durante as campanhas eleitorais, que apoiaria Dilma Rousseff, como foi mostrado na introdução deste trabalho. Então, a vitória de Dilma foi também a vitória da revista, que "acertou" em seu candidato. Acionando esta memória, justifica-se o destaque da revista ao resultado das eleições, com uma edição especial, em uma capa totalmente dedicada a quem eles apoiaram desde o início.

Já a edição posterior, de 5 de novembro, com mais tempo para apuração e menos comemorações, traz análises dos políticos Ciro Gomes, Delfim Netto, Jaques Wagner e Revista Em Debate (UFSC), Florianópolis, volume 16, p. 15-40, 2016. ISSNe 1980-3532 
Renato Janine Ribeiro. O assunto principal é o novo ministério - da Fazenda - com o debate sobre o que fazer com a economia e quem seria o mais indicado ao cargo, à época em aberto. Além disso, diferentemente do Especial Eleições, CartaCapital colocou na capa uma chamada para a Lava-jato, citando inclusive a revista Veja, chamando-a de farsante, e a crise hídrica de São Paulo, citando o governador Geraldo Alckmin, do PSDB.

Figura 4 - Capa de CartaCapital em 5 de novembro de 2014

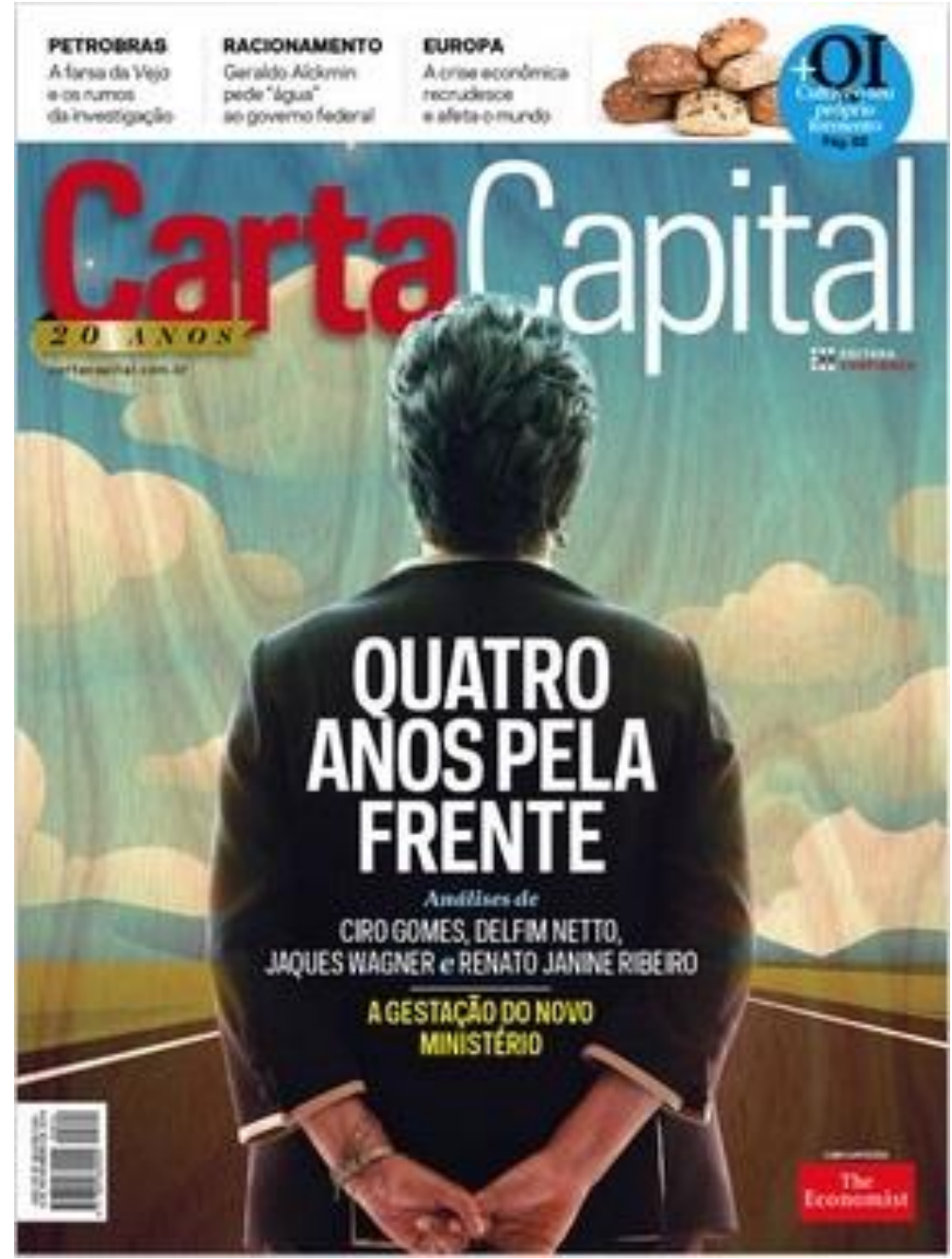

Fonte - Revista CartaCapital (2014)

"Quatro anos pela frente" é o que diz a manchete de CartaCapital, com a imagem de Dilma Rousseff de costas, mirando uma paisagem que representa o futuro. Pode-se dizer que ela está "olhando para frente". Abaixo disso, a chamada para as análises de Ciro Gomes, Delfim Netto, Jaques Wagner e Renato Janine Ribeiro e "a gestação do novo Ministério", referindo-se ao Ministério da Fazenda, até então sem Revista Em Debate (UFSC), Florianópolis, volume 16, p. 15-40, 2016. ISSNe 1980-3532 
ninguém à frente, mas também fazendo relação aos cuidados que uma mãe deve ter durante uma gestação, ou seja, recomendando cautela e cuidados a Dilma. Não há aqui referência a qualquer tipo de exaustão ou cansaço, no entanto há a consciência de que a oposição será dura e, por isso há a necessidade de tomar cuidado.

Além de estar de costas, Dilma aparenta ter uma luz incidindo em si, na frente, como se o futuro fosse um caminho de luz, de prosperidade. Este não-dito indica uma análise positiva dos assuntos tratados pelos analistas trazidos pela revista. Neste momento, aparece a lei da pertinência, também apresentada por Maingueneau (2002), pois uma análise do novo mandato de Dilma, sobretudo na economia, é pertinente aos leitores da revista, que devem buscar nela alguma notícia sobre a presidenta e, além disso, buscam algo de positivo, alguma esperança. No entanto, cabe fazer um destaque para a cor da roupa que, diferente da edição anterior que estava colorida (vermelha), agora está mais escura. Uma escuridão do presente, com as dificuldades enfrentadas desde já.

Por enquanto, sobressai a positividade. No entanto, isso cai por terra nas chamadas que falam da Operação Lava-jato, que não é citada diretamente, mas mencionada no título "a farsa da Veja e os rumos da investigação" (CARTACAPITAL, 2014). A revista cita a capa de Veja, em edição antecipada para dois dias antes da eleição para o segundo turno - e já citada aqui anteriormente -, em que afirmava que Lula e Dilma "sabiam de tudo". A palavra "farsa" remete a enganação, por isso é um juízo de valor. É um termo usado de forma pejorativa, que chama a revista Veja de mentirosa, em outras palavras.

Logo após, seguindo o mesmo ritmo, a CartaCapital traz a crise hídrica de São Paulo, com “Geraldo Alckmin pede 'água' ao governo federal”, colocando o governador paulista se inclinando ao governo, mesmo sendo do partido oposto (PSDB), que também foi o perdedor das eleições, com Aécio Neves. De alguma forma a revista indica que mesmo sendo oposição será necessário negociar, pois existem necessidades que serão supridas com a ajuda do governo federal. No entanto silencia-se sobre o adversário direto na eleição, Aécio, tanto na imagem quanto na escrita.

Após esta análise das quatro capas, é hora de adentrar no conteúdo das revistas. Serão apresentadas algumas matérias que tratam dos desdobramentos das eleições, que demonstram a polarização que o país já vivia e que ficaria ainda mais acirrada após o resultado das eleições.

Revista Em Debate (UFSC), Florianópolis, volume 16, p. 15-40, 2016. ISSNe 1980-3532 
Veja e CartaCapital também falam sobre a nação partida ao meio, argumento escutado após as votações, que teve resultado apertado, com 51,64\% para a petista e 48,36\% para o candidato tucano. Ambas as publicações tentam desmitificar isso, mas cada uma do seu jeito. Veja coloca o "Mito da nação partida ao meio", título da matéria, como algo positivo, pois mostra o crescimento do PSDB nas últimas eleições, ou seja, mesmo não saindo vencedor no pleito houve crescimento. Além disso, o termo 'mito' é usado aqui para indicar uma mentira que deve ser esclarecida. Já CartaCapital, nas palavras mais comedidas de Jacques Wagner, aponta para a vitória da democracia. "O Brasil não se dividiu", é o que diz.

O País empolgou-se com dois projetos políticos apresentados. As nossas diferenças existem e devem ser assumidas para que possam ser superadas, mas na pluralidade a nossa unidade deve ser sempre protegida. A democracia é nosso bem maior. E a democracia é o território do diálogo, do contraditório e do embate de ideias. Ela não resiste à intolerância e a qualquer tipo de fundamentalismo. E nosso país é uma democracia complexa, com múltiplas tonalidades. Tentar reduzi-la é empobrecer e simplificar o debate. (CARTACAPITAL, 2014, p. 30)

Já a revista Veja, logo abaixo do título, coloca seu ponto de vista para a não divisão do país ao meio. "Com toda a tragédia, todas as reviravoltas e toda a paixão, a disputa de 2014 está sendo vista como marco na cisão nacional, mas é o contrário: num ritmo sólido e lento, próprio de países estáveis, o eleitor está-se afastando do PT, eleição após eleição" (VEJA, 2014, p. 86). As duas apresentam palavras favoráveis à democracia, mas Veja dá a tônica de sua análise do cenário das eleições. Além disso, indica que, mesmo de maneira lenta, o Brasil está se tornando um lugar com certa estabilidade, característica muitas vezes ligada aos países desenvolvidos, e em um lugar como esse não há lugar para partidos como o PT.

Nestas matérias, manifesta-se o interdiscurso e o intradiscurso, que surgem quando a memória é ativada e elas proferem este discurso - já existente - como se ninguém o houvesse usado ainda (ORLANDI, 2007). As duas revistas usam um discurso já utilizado antes para colocarem suas posições, através de argumentos e números. Cabe ressaltar, nesta reportagem detalhada de Veja, a precisão de dados.

Tome-se o caso da região mais populosa e rica do Brasil, o Sudeste. Nos quatro estados da região, Aécio conseguiu 25,5 milhões de votos, mas Dilma recolheu 19,9 milhões. Obviamente, foi um desempenho decisivo para a sua vitória. Na região Sul, em que Aécio venceu com 9,7 milhões de votos, 6,8 milhões de eleitores optaram por Dilma. (VEJA, 2014, p. 87) 
Por mais que uma matéria que apresente muitos números possa atrapalhar o leitor, a exatidão nos dados é uma virtude que deve ser repetida, pois o leitor consegue interpretar com mais precisão o que lhe é passado. Isso pode ser visto na prática, com o contraponto da outra revista. No trecho indicado também se percebe o silêncio quanto às outras regiões do país. Não se fala em Norte e Nordeste, no entanto, justamente ao não falar a publicação pode levar o leitor a seguinte conclusão: ora se a candidata perdeu nessas regiões ela deve ter ganhado em outras. Que outras são essas? Qual o imaginário construído em torno delas? As respostas que os leitores encontrarem para essas perguntas pode contribuir para a polarização que, dessa vez pode transcender ao discurso político. Interessante perceber que o imaginário relacionado às outras regiões do Brasil é acionado na revista ao afirmar que a região Sudeste é 'a mais populosa e rica'. Há ai o pressuposto, algo que não precisa ser dito: 1) que a região Sul, juntamente com a Sudeste, compõem os locais mais ricos do Brasil e 2) os locais onde Dilma ganhou são mais pobres.

Em CartaCapital, respondendo a questão já apresentada anteriormente, sobre quem incentivou a ideia da divisão do Brasil, Renato Janine Ribeiro usa números aproximados, com achismos que não engrandecem o debate. "Mas acho que ao menos $50 \%$ dos brasileiros não dão muita importância à política. Entre aqueles $30 \%$ ou $40 \%$ que dão, há um profundo antagonismo. Mas vejo essa revolta, essa intolerância, mais no eleitorado tucano" (CARTACAPITAL, 2014, p. 29).

Para expressar uma opinião particular, Janine usa de dados que podem não ser verdadeiros e que, por isso, não deveriam ser utilizados, pois podem servir de base a outras pessoas. Fosse somente para criticar o discurso de ódio que ele vê mais do lado tucano, não precisaria embasar com números dos quais ele não tem certeza se existem.

Aqui vale ressaltar a lei da exaustividade, expressa por Maingueneau (2002). Nela, o autor afirma ser obrigatório que o enunciado conceda a informação máxima. Portanto, pode-se considerar que Veja consegue seguir esta lei à risca, pelo que foi mostrado acima, ao contrário de CartaCapital, que usa de números estimados para expor uma outra opinião.

Pulando para a edição de 12 de novembro, Veja fala de "Dilma e seu labirinto", citando o isolamento dela pós-vitória e apresentando equívocos de Dilma nos discursos antes da votação e que, depois de vencer, caíram por terra. Mesmo assim, a matéria mostra Aécio Neves como um vencedor e a presidenta como uma derrotada moral.

Revista Em Debate (UFSC), Florianópolis, volume 16, p. 15-40, 2016. ISSNe 1980-3532 
Dilma viu Aécio Neves, o candidato que ela derrotou, ser recebido em triunfo em Brasília, aclamado como líder, enquanto ela se isolou no Palácio, com a melancolia de quem não tem o que comemorar verdadeiramente por, talvez, não ter perguntado a si mesma antes, não 'como' ganhar as eleições, mas 'por quê' e 'para quê'." Estas são as palavras da reportagem, que colocam a pessoa vitoriosa como perdida e a pessoa derrotada como vitoriosa. (VEJA, 2014, p. 58)

Incansável no destaque positivo do ex-candidato, em 12 de novembro Veja volta a exaltar seu retorno a Brasília.

Derrotado, mas carregando um vistoso balaio de 51 milhões de votos, o tucano Aécio Neves voltou para Brasília depois do descanso pós-eleitoral e recebeu - ao desembarcar do avião de carreira, ao deixar o aeroporto, ao chegar ao Congresso, ao entrar no plenário - tratamento normalmente dado às celebridades, com centenas de admiradores gritando seu nome. (VEJA, 2014, p. 71)

Veja colore a página dupla com um Aécio sorridente, cercado por fotógrafos e curiosos, mostrando ser real o que apresentou, mas sem esconder também sua felicidade nisso.

"Agora, Aécio quer ser uma oposição digna ao PT". A revista Veja também mostra sua predileção por ele ao afirmar, após o trecho anterior, que essa é "a primeira condição para fazer uma oposição eficaz: ter um líder popular e com algum carisma”. Outra vez percebe-se o pressuposto: não é necessário repetir ao leitor o que é carisma ou ser popular, nem ao menos dizer que Aécio é popular: a imagem o faz, sem palavras. Em entrevista no dia 5 de novembro, é Aécio quem responde, após ser perguntado pela reportagem se

sem trégua nem lua de mel, como disse o senador (e candidato a vice na
chapa tucana) Aloysio Nunes?: Os 51 milhões de brasileiros que se puseram
na oposição nas eleições esperam que seus representantes no Congresso
sejam vigilantes e firmes. Que se oponham ao governo, e não ao país.
Seremos firmes porque nossos eleitores reprovaram nas urnas os métodos do
PT, sua visão de mundo, seus desvios éticos, a forma como compõe o
governo e a forma como governa. Não vamos permitir que o governo desvie
a atenção dos brasileiros do maior escândalo de corrupção da nossa história,
o da Petrobras. (VEJA, 2014, p. 84)

Interessante analisar o que Aécio considera ser oposição ao governo e não ao país. Tal afirmação feita pelo candidato derrotado pode pressupor ao leitor que todas as propostas feitas pelo governo seja ruins para o país no entanto, se a proposta for boa ao país a oposição será feita apenas para ser contra o governo? O discurso dele está alinhado ao da própria revista, quando fala do "maior escândalo de corrupção da nossa história". Além disso, Aécio, ao separar os eleitores dele e os de Dilma, como se eles Revista Em Debate (UFSC), Florianópolis, volume 16, p. 15-40, 2016. ISSNe 1980-3532 
tivessem interesses distintos, como se os dele desejassem o melhor ao país e os de Dilma não, contrapõe o argumento do "mito do país dividido ao meio", porque se eles tem interesses distintos, então o país está dividido em Aécio versus Dilma. Sem falar na oposição proposta por Aécio. Uma oposição ferrenha a um partido pode acabar afetando o futuro do país, pois compromete a aprovação de leis, por exemplo, que podem ser fundamentais para a nação. Nesse sentido, ao ouvir apenas Aécio, além do fato da população estar em lados opostos, parece indicar um silenciamento quanto a quem é o vencedor. Assim, há o apagamento do discurso do vencedor. Assim, quem fará o bem, a partir desse silêncio, é quem foi ouvido, aquele que, de fato não ganhou as eleições.

Veja insere, nas matérias sobre oposição, uma formação discursiva e ideológica para reafirmar a dominância do candidato tucano na oposição que ela deseja que seja feita. A revista pertence à classe da oposição - dominante - e deseja que ela se reafirme (BRANDÃO, 2004). Liedtke (2002) insere a mídia como principal agente discursivo da sociedade. Ela consegue manter partidos no poder ou ser sua oposição, como é o caso de CartaCapital e Veja. No entanto, a política também pode agir sobre a mídia. De qualquer forma, ambas resultam de uma tentativa de hegemonia política, feita através da ideologia e do discurso (MARIANI, 1996).

$\mathrm{Na}$ edição especial de eleições, de 29 de outubro, CartaCapital (2014, p. 12) afirma que "A democracia vence o golpe - Dilma Rousseff supera a tentativa da mídia de interferir nas eleições e derrota Aécio Neves em uma disputa acirrada". A menção à mídia certamente é para a Veja, pelo motivo já citado anteriormente, que foi interpretado por CartaCapital e pelo PT como uma manobra para tirar votos de Dilma e depositá-los em Aécio, fazendo com que este saísse vitorioso nas urnas. Segundo CartaCapital (2014, p. 12), foi um "triunfo da politização da maioria do eleitorado, certo de que o governo petista ainda é a aposta certa para melhorar a vida dos mais pobres e dos trabalhadores".

Isso está ligado ao contexto, explicado por Maingueneau (2002). CartaCapital comemora a vitória de Dilma, mas não esquece do que considera um golpe - ou a tentativa de um - feito pela revista opositora. Nisso se insere o ambiente físico da enunciação, o contexto situacional. "Valendo-se do contexto situacional, podem-se interpretar unidades" (MAINGUENEAU, 2002, p. 27). A unidade é a revista que fala, destinada a um leitor/consumidor, que é o receptor das informações. 
Em editorial, Mino Carta cita de novo a vitória de Dilma "contra a reação golpista". Antes das eleições, ele publicou texto explicando seu apoio à candidata. Dessa vez, o que fez foi justificá-lo.

Aí está o sentido do apoio de CartaCapital à permanência da presidenta Dilma. Sua vitória é a garantia da continuidade da política social e da política exterior independente executadas nos últimos 12 anos. Ganhamos agora a certeza de que o neoliberalismo não vingará, que o salário mínimo não será cortado, que a Petrobras não será privatizada, que o pré-sal não será loteado. (CARTACAPITAL, 2014, p. 15)

Ao anunciar estas palavras Mino Carta se coloca como um vitorioso também nas eleições. Além disso, não só ele, mas a revista CartaCapital é colocada como apoiadora de Dilma. Através deste editorial, o fundador das duas revistas aqui analisadas (SCALZO, 2006), deixa clara sua reprovação pelas ações de Veja e sua predileção pelo que faz CartaCapital e pelo que faz e fez o governo do PT desde 2002, quando foi colocado no poder.

Mino Carta, nessas palavras, usufrui do não-dito (ORLANDI, 2007) no fim do trecho destacado. Ao dizer que com Dilma “o neoliberalismo não vingará, que o salário mínimo não será cortado, que a Petrobras não será privatizada, que o pré-sal não será loteado" (CARTACAPITAL, 2014, p. 15), ele deixa pressuposto e subentendido que, em caso de vitória tucana, isso tudo ocorreria, o que não se sabe se é verdade ou não. Deixando algo implícito, Mino Carta fere uma das leis do discurso, explicadas por Maingueneau (2002): a da modalidade. Tal lei afirma ser necessária clareza nas palavras usadas e não o uso de obscuridades, como é o caso do editorial de CartaCapital que, portanto, não cumpre esta lei, importante para o entendimento do leitor.

O que se fez, até aqui, foi a análise de duas edições das revistas CartaCapital e outras duas de Veja, que foram publicadas após as eleições para o segundo turno de 2014, a fim de estabelecer a abordagem delas. Como recomendado por Orlandi (2007), foi necessário remeter os discursos às formações discursivas, condições de produção, enfim, diversas formas de empreender a análise da melhor forma possível. No próximo capítulo serão feitas as conclusões deste trabalho e da análise. Com isso, será visto se os objetivos propostos no início obtiveram êxito ou não.

\section{Considerações finais}


Este artigo foi produzido como uma adaptação de uma monografia elaborada pelo autor em 2015, quando a abordagem das revistas fora analisada, com outros objetivos e outra conclusão. A adaptação foi realizada para que fizesse parte da temática proposta.

A pesquisa aqui empreendida foi feita sob o questionamento se na abordagem das matérias das revistas Veja e CartaCapital, nas edições que sucederam as eleições para a presidência de 2014, é possível verificar a polarização discursiva? Como demonstrado, a forma escolhida para esta verificação foi a análise embasada na teoria da análise do discurso e seus ensinamentos acerca de ideologia, condições de produção, etc.

Através da análise, constatou-se que o conteúdo publicado nas revistas influencia na opinião pública, de forma a aumentar a polarização nas ruas e na internet, através do discurso. Como registrado, até ataques diretos CartaCapital fez à Veja. Além disso, termos como "golpe", "oposição", "medo", dentre outras, todas com sentido pejorativo, recaem sobre uma rivalidade que sai das páginas da revista para o vocabulário da população o que indica o poder que a mídia tem como agente discursivo na sociedade em que se insere. Além disso, essa percepção de que a polarização vista nas ruas está presente nas páginas das revistas reforça a ideia de que o veículo de comunicação pode ser compreendido como o microcosmos social.

Juízos de valor devem ser usados com cuidado, pois, analisados atentamente, demonstram seu verdadeiro sentido e dão outro tom à publicação, fazendo com que ela pareça irônica, por exemplo. E o tom irônico é mais presente em Veja do que em CartaCapital, que prefere ser mais comedida neste aspecto. CartaCapital chama Veja de farsante, ou seja, de mentirosa, mesmo sem haver algo de concreto para tal informação. Já Veja insiste em colocar a Operação Lava-jato com o maior esquema de corrupção da história do país e vincula isso ao PT e a Dilma.

À guisa de conclusão, as duas revistas apresentaram em seus discursos maneiras de defender seus interesses, sua hegemonia, tudo isso sem perder a oportunidade de citar a outra, mesmo indiretamente. Este trabalho comprovou que por trás de cada palavra há outro significado, mais profundo, mas igualmente importante, que deveria ser notado pelos leitores, mas dificilmente o é, devido em parte à falta de intimidade com questões de linguagem e, de outra parte, pela dificuldade em se ter contato com dois tipos de revistas tão diferentes, que retratam a verdade cada qual de seu jeito. 
De qualquer modo, o trabalho não se finda nele mesmo e a pesquisa fica em aberto uma vez que mudanças ocorrem na política nacional a todo momento, Veja e CartaCapital podem adotar outro tom, ou seja, outro discurso que, como todo discurso, está impregnado de ideologias e significados que valem sempre ser debatidos e expostos, tal qual foi tentado e, espera-se, alcançado aqui.

\section{Referências}

BRANDÃO, Helena H. Nagamine. Introdução à análise do discurso. 2. ED. Campinas, SP: Unicamp, 2004.

CARTA, Mino. Por que escolhemos Dilma Rousseff, 2014. Disponível em: http://www.cartacapital.com.br/revista/807/por-que-escolhemos-dilma-rousseff131.html/ (Acesso em 27 de abr. de 2015)

CARTACAPITAL. São Paulo: Confiança, ano 20, ed. 823, out. 2014

CARTACAPITAL. São Paulo: Confiança, ano 20, ed. 824, nov. 2014

GIL, Antônio Carlos. Como elaborar projetos de pesquisa. 4. ED. São Paulo, SP. Atlas, 2002.

LIEDTKE, Paulo Fernando. A esquerda presta contas: comunicação e democracia nas cidades. Itajaí/ SC, Ufsc; Univali, 2002.

MAINGUENEAU, Dominique. Análise dos textos de comunicação. 2. ED. São Paulo, SP: Cortez, 2002.

MARIANI, Bethania Sampaio Corrêa. O comunismo imaginário: práticas discursivas da imprensa sobre o PCB (1922-1989). Tese (Doutorado em Linguística) Universidade de Campinas. São Paulo, SP, 1996.

Mídia Kit $2015 \quad$ - Carta Capital. Disponível em: https://www.editoraconfianca.com.br/formatos_html/assets/editoraconfianca_20_07.pdf (Acesso em 23 de fez. de 2017)

ORLANDI, Eni P.. Análise do discurso: princípios e procedimentos. 7. ED. Campinas, SP: Pontes, 2007.

SCALZO, Marília. Jornalismo de revista. 3. ED. São Paulo, SP: Contexto, 2006.

SEABRA, Roberto; SOSA, Vivaldo (orgs.). Jornalismo Político: teoria, história e técnicas. Rio de Janeiro, RJ: Record, 2006.

VEJA. São Paulo: Abril, ano 47, ed. 2397, out. 2014 
VEJA. São Paulo: Abril, ano 47, n. 2398, nov. 2014

VEJA. São Paulo: Abril, ano 47, ed. 2399, nov. 2014.

VELLOSO, Monica Pimenta. Percepções do moderno: as revistas do Rio de Janeiro. In: NEVES, Lúcia Maria Bastos P.; MOREL, Marcos; FERREIRA, Tania Maria Bessone da C. (orgs.). História e imprensa: representações culturais e práticas de poder. Rio de Janeiro: DP\&A: Faperj, 2006. p. 312 - 331. 